\begin{tabular}{c} 
Media Kesmas (Public Health Media) \\
e-ISSN 2776-1339 \\
https://jom.htp.ac.id/index.php/kesmas \\
\hline
\end{tabular}

\title{
Analisis Pengelolaan Sampah Anorganik Di Desa Parit 1 Api-Api Kecamatan Bandar Laksamana Tahun 2020
}

\author{
Gilang Tu Ramadhan ${ }^{1}$, Sherly Vermita Warlenda ${ }^{2}$, Beny Yulianto ${ }^{3}$ \\ 1,2,3 STIKes Hang Tuah Pekanbaru \\ Korespondensi : sherlyvermita130988@gmail.com
}

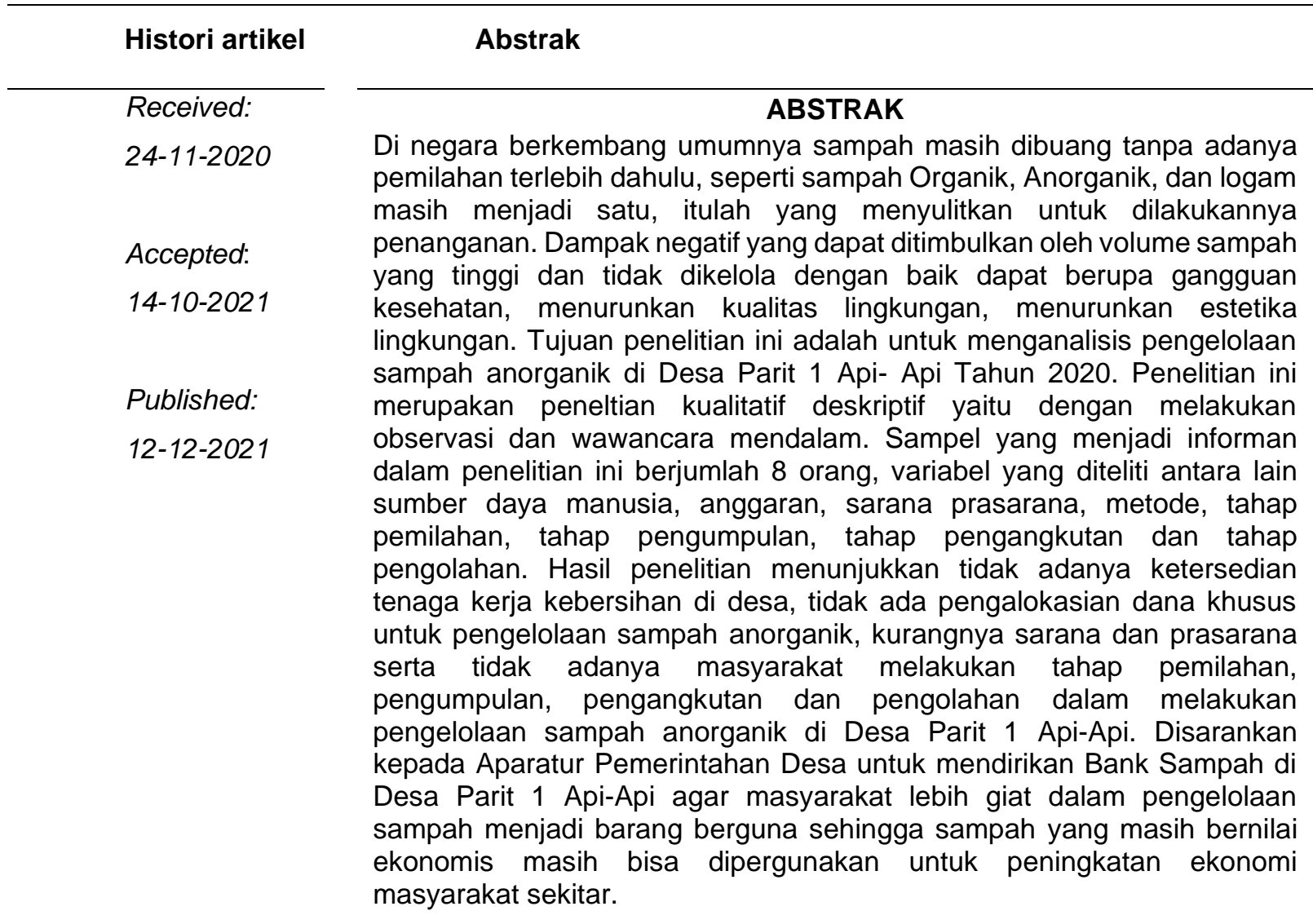

Kata Kunci : Pengelolaan Sampah, Anorganik, Desa Parit 1 ApiApi

\section{ABSTRACT}

In developing countries, generally waste is still discarded without prior sorting, such as organic, inorganic, and metal waste is still one, which 
makes it difficult for handling. The negative impacts that can be caused by high volumes of waste that are not managed properly can be in the form of health problems, reducing environmental quality, reducing environmental aesthetics. The purpose of this study was to analyze the management of inorganic waste in the Village of Parit 1 Api-Api in 2020. This research was a descriptive qualitative research by conducting in-depth observations and interviews. The number of informants in this study amounted to 8 people, the variables studied included human resources, budget, infrastructure, methods, sorting stage, collection stage, transportation stage and processing stage. The results showed that there was no availability of sanitation workers in the village, no allocation of special funds for the management of inorganic waste, lack of facilities and infrastructure as well as the absence of the community carrying out the stages of sorting, collecting, transporting and processing in managing inorganic waste in the Village of Parit 1 Api-Api. Researchers suggest to the Village Government Apparatus to establish a Trash Bank in the Village of Trench 1 Api-Api so that the community is more active in managing waste into useful goods so that waste that is still of economic value can still be used to improve the economy of the surrounding community.

Keywords: Waste Management, Anorganic, Parit 1 Api-Api Village

\section{PENDAHULUAN}

Jumlah penduduk sangat mempengaruhi dari jumlah timbulan sampah yang dihasilkan per individu. Pemerintah saat ini telah berupaya dengan berbagai cara untuk mengatasi masalah sampah. Terutama masalah sampah an-organik. Tetapi permasalahan sampah tersebut belum mencapai titik kesempurnaan akibat daripada angka jumlah sampah yang ada di Indonesia sangat tinggi sehingga pemerintah kesulitan untuk menyeslesaikan permasalahan pengurangan sampah.

Di negara berkembang umumnya sampah masih dibuang tanpa adanya pemilahan terlebih dahulu, seperti sampah organik, non organik, dan logam masih menjadi satu, itulah yang menyulitkan untuk dilakukannya penanganan. Pengelolaan sampah seperti ini sebagian tata laksananya masih bertumpu pada pemerintah. Bertambahnya jumlah penduduk, perubahan pola konsumsi, dan gaya hidup masyarakat yang berubah ubah dapat meningkatkan jumlah, jenis, dan keberagaman karakteristik sampah Sartika (2018).

Rumitnya permasalahan sampah yang terjadi di Indonesia diakibatkan oleh beberapa hal, pertama akibat kurangnya pengertian dari masyarakat terhadap akibat- akibat yang dapat ditimbulkan oleh sampah dan kedua kurangnya biaya pemerintah untuk mengupayakan pengelolaan sampah yang baik dan benar. Pengaruh sampah terhadap kesehatan dapa dikelompokkkan menjadi efek langsung dan tidak langsung. Efek langsung adalah efek yang 
disebabkan karna kontak langsung dengan sampah seperti, sampah beracun, sampah yang bersifat korosif terhadap tubuh. Sedangkan efek tidak langsung berupa penyakit bawaan vector yang berkembangbiak dalam sampah sehingga menjadi sarang bagi hewan seperti lalat, tikus, nyamuk dan hewan lainnya yang dapat menyebarkan penyakit (Fitra, 2017).

Dampak negatif yang dapat ditimbulkan oleh volume sampah yang tinggi dan tidak dikelola dengan baik dapat berupa gangguan kesehatan, menurunkan kualitas lingkungan, menurunkan estetika lingkungan dan terhambatnya pembangunan negara. Pengelolaan sampah berlangsung dengan baik dapat mencegah dari timbulnya berbagai penyakit, maka setiap kegiatan pengelolaan sampah harus mengikuti filosofi sampah dimana semakin sedikit dan semakin dekat sampah dikelola dari sumbernya, maka pengelolaannya yang dilakukan menjadi efektif dan baik, serta lingkungan yang terkena dampak jugas semakin sedikit (Marliani, 2014).

Desa Parit 1 Api-api adalah sebuah desa yang terletak diwilayah Kecamatan Bandar Laksamana, Kabupaten Bengkalis dengan luas 642 Ha yang mana sebelah Barat berbatasan dengan Desa Temiang, Utara berbatasan dengan Desa Api-Api, Timur berbatasan dengan Selat Bengkalis, dan Selatan berbatasan dengan Desa Sukajadi. Desa Parit 1 Api-Api terdiri dari 2 dusun, 2 RW dan 6 RT mempunyai jumlah penduduk 874 jiwa, yang terdiri dari Lakilaki 458 jiwa dan Perempuan 416 jiwa dengan total

224 kepala keluarga. Mata pencaharian masyarakat di Desa Parit 1 Api-Api mayoritas bertani dan berkebun.

Berdasarkan survei awal yang peneliti lakukan, di Desa Parit 1 Api-Api terdiri dari

2 dusun, 2 RW dan 6 RT sampah yang dihasilkaan kebanyakan berupa sampah organik dan sampah an-organik. Menurut survei secara langsung yang dilakukan untuk jenis sampah ini masih ditemukan berserakan khusunya sampah yang di buang di selokan, dan rata-rata masyarakat di Desa Parit 1 Api- Api tidak melakukan pengelolaan sampah sehingga masyarakat masih melakukan pengelolaan sampah dengan cara dibakar, seperti yang kita ketahui melakukan pengelolaan sampah dengan cara dibakar ini merupakan metode gaya lama yang sudah turun temurun mereka lakukan. Masyarakat beranggapan sampah yang dibakar habis tidak meninggalkan dampak bagi mereka sehingga banyak dari masyarakat yang mengelola sampah dengan cara ini. Tetapi ada beberapa warga yang sudah melakukan pengolahan sampah khususnya sampah an- organik untuk dijadikan kerajinan dan cinderamata. Pengolahan tersebut diatur langsung Kepala Desa dan di beri arahan kepada ibu PKK (Pemberdayaan Kesejahteraan Keluarga) yang sudah berlangsung lebih kurang 3 
tahun belakangan, tetapi akibat kurangnya antusias dari warga desa mengakibatkan program tersebut tidak berjalan dengan baik.

Di Desa Parit 1 Api-Api tidak tersedia Tempat Pembuangan Sampah Sementara (TPS) sehingga masyarakat lebih memilih untuk membakar sampah sebagai pilihan utama penanganan sampah di wilayah mereka. Akibat yang ditimbulkan oleh pembakaran sampah ialah dapat menimbulkan bahaya polusi udara di Desa Parit 1 Api-Api sehingga dapat merusak dan membahayakan kesehatan masyarakat sekitar pemukiman bahkan menimbulkan penyakit. Kurangnya pemahaman dan kesadaran masyarakat dalam pemilahan sampah menjadi fokus utama, tetapi ada beberapa masyarakat yang sudah tahu cara pengelolaan sampah dan pemilahan tetap saja masih melakukan pembakaran sampah.

Selain sampah rumah tangga juga diketahui sumber sampah terdapat pada pasar yang berada di Desa Parit 1 Api-Api yang diadakan setiap Hari Sabtu. Potensi sampah yang dihasilkan di pasar ini juga cukup banyak, sampah di pasar ini berupa sampah organik dari sayur-sayuran dan juga bersumber dari sampah an-organik. Jenis dagangan yang dijual disini adalah kebutuhan sehari-hari seperti sayur-sayuran, daging, sembako, peralatan rumah tangga. Ketidaktersedian TPS dari lokasi perdagangan menyebabkan sulitnya pedagang untuk membuang sampah pada tempat yang telah disediakan, sehingga menyebabkan masih didapatinya sampah- sampah yang berserakan diarea pasar, banyak orang yang membuang sampah sembarangan baik penjual maupun pembeli yang berkunjung ke pasar yang berada di Desa Parit 1 Api-Api dan pengelola pasar tersebut masih melakukan metode lama dalam pengelolan sampah yaitu dengan cara dibakar akibat dari pengelolaan sampah di Desa Parit 1 Api-Api tersebut tidak ada. Tentu saja hal ini dapat menyebabkan lingkungan pasar menjadi tidak nyaman, dan dapat merusak ekosistem lingkungan dan pasar baik dari segi estetika dan menggangu pernafasan karena bau yang tersebar disekitar pasar yg disebabkan oleh sampah yang menumpuk, berserakan dan dibakar.

Seharusnya hal ini menjadi permasalahan serius bagi penjual, pengelola pasar, maupun masyarakat karena dapat mengakibatkan timbulnya penyakit dan menyebabkan gangguan kesehatan yang dapat merugikan masyarakat Desa Parit 1 Api-Api itu sendiri. Tujuan penelitian untuk Mengetahui Analisis Pengelolaan Sampah An-organik di Desa Parit 1 ApiApi Kecamatan Bandar Laksamana Tahun 2020.

\section{METODE}

Penelitian ini merupakan penelitian kualitatif dilakukan di Desa Parit 1 Api-Api Kecamatan Bandar Laksamana pada bulan Februai-Mei Tahun 2020. Subjek/sampel yang menjadi 
informan dalam penelitian ini berjumlah 5 orang. Alat yang digunakan untuk membantu adalah panduan wawancara, alat tulis, lembar observasi, HP sebagai alat perekam dan kamera digital sebagai dokumentasi.

\section{HASIL}

\section{Karakteristik Responden}

Jumlah responden sebanyak 8 orang diantaranya adalah 1 Orang Kepala Desa, 2 Orang Kepala Dusun, 2 Orang Ketua RT dan 3 Orang warga Desa Parit 1 Api-Api. Karakteristik dari masing-masing responden secara keseluruhan berdasarkan umur, jenis kelamin, pendidikan dan jabatan.

Tabel 1 Karakteristik Informan

\begin{tabular}{|c|c|c|c|c|}
\hline \multicolumn{5}{|c|}{ Karakteristik } \\
\hline Kode & $\begin{array}{l}\text { Umur } \\
\text { (Tahun) }\end{array}$ & $\begin{array}{l}\text { Jenis } \\
\text { Kelamin }\end{array}$ & Pendidikan & Jabatan \\
\hline Informan 1 & 48 & Laki-laki & SLTA & Kepala Desa \\
\hline Informan 2 & 38 & Laki-laki & SLTA & $\begin{array}{l}\text { Kepala Dusun } \\
\text { Kenanga Muda }\end{array}$ \\
\hline Informan 3 & 38 & Laki-laki & SLTA & Kepala Dusun Melati \\
\hline Informan 4 & 74 & Laki-laki & SLTA & Ketua RT 04 \\
\hline Informan 5 & 50 & Laki-laki & SD & Ketua RT 05 \\
\hline Informan 6 & 43 & Perempuan & DIPLOMA 1 & $\begin{array}{l}\text { Warga Desa Parit } 1 \\
\text { Api-Api }\end{array}$ \\
\hline Informan 7 & 49 & Laki-laki & SMA & $\begin{array}{l}\text { Warga Desa Parit } 1 \\
\text { Api-Api }\end{array}$ \\
\hline Informan 8 & 50 & Perempuan & SMA & $\begin{array}{l}\text { Warga Desa Parit } 1 \\
\text { Api-Api }\end{array}$ \\
\hline
\end{tabular}

\section{Wawancara}

\section{a. Sumber Daya Manusia (SDM)}


Dari hasil wawancara yang telah dilakukan dilapangan diperoleh bahwa untuk ketersediaan tenaga kerja yang menangani sampah an-organik di Desa Parit 1 Api-Api tidak tersedia, masyarakat masih secara individual melakukan pembersihan sampah dengan cara dibakar dan adapun masyarakat yang membuang ke parit. Sampah yang dihasilkan dari aktivitas warga ditumpuk dihalaman rumah atau dibelakang rumah warga masing- masing untuk selanjutnya dilakukan proses pembakaran sampah. Hal tersebut dapat dilihat dari hasil wawancara yang telah dilakukan terhadap responden berikut :

Bagaimana menurut bapak/ibu ketersediaan tenaga kerja untuk melakukan pengelolaan sampah anorganik di Desa Parit 1 Api-Api ?

“...Kalau untuk di desa ketersedian tenaga kerja nya sudah ada dengan 2 kelompok yang dilakukan pelatihan di duri dengan jumlah 20 orang, dan untuk pengelola sampah dipasar sudah termasuk dari 20 orang tersebut sebagai pengelola sampahnya, sampah tersebut diambil dan di daur ulang kembali. (Responden 1)..."

\section{b. Dana/Anggaran}

Anggaran dana tidak tersedia untuk pengelolaan sampah anorganik di desa Desa Parit 1 Api- Api, baik anggaran desa maupun pungutan biaya kebersihan kepada pihak masyarakat, hal ini dapat dilihat dari hasil wawancara mendalam yang telah dilakukan terhadap responden sebagai berikut :

Bagaimana dana/anggaran di desa dan pungutan biaya kebersihan untuk masalah kebersihan di Desa Parit 1 Api-Api ? Jika ada berapa dan kapan waktunya?

“...Kita kalau untuk dana daur ulang sampah mempunyai dana sendiri dari pemberdayaan atau bintek, hasil dari pada kegiatan tersebut digunakan kegiatan lainnya. 2018 kemaren sempat pernah juga mengundang dari pihak instansi luar dalam pengelolaan sampah dan Alhamdulillah mendapati posisi yang baik. (Responden 1)...”

“...Belum ada, cuman masyarakat melakukan nya dengan gotong royong (Responden 2)..."

\section{c. Sarana dan Prasarana}

Ketersediaan sarana dan prasarana untuk pengelolaan sampah anorganik di Desa Parit 1 Api-Api seperti kendaraan pengangkut sampah dan ketersediaan TPS sementara di desa tidak tersedia sama sekali.

\section{d. Metode}


Metode yang masyarakat Desa Parit 1 Api-Api lakukan untuk pembersihan sampah anorganik masih dengan metode lama yang sudah sejak dahulu kala mereka lakukan, yaitu dengan cara membakar sampah dan adapun sampah yang masih dibuang di parit. Masyarakat lebih memilih metode ini karna dinilai lebih praktis dan tidak memakan biaya banyak, tanpa memikirkan bahaya yang mungkin dapat terjadi tanpa disadari oleh mereka. $\mathrm{Hal}$ ini dapat dilihat dari hasil wawancara mendalam yang peneliti lakukan terhadap responden sebagai berikut :

\section{1) Tahap Pemilahan}

Bagaimana menurut bapak, sudahkah masyarakat melakukan pemilahan sampah anorganik terlebih dahulu?

“...Kalau dalam hal itu belum ada, karena dari masyrakat saya sendiri belum paham dan kurang action nya akibat beliau kurang memahami karena kami harus jeli juga memberikan masukan terhadap masyrakat atas manfaat yang didapat dari sampah tersebut sebab sampah itu bermanfaat tinggi, karena sampah yang dibuang orang di pinggir-pinggir jalan yang dibuang orang lewat tu mempunyai manfaat besar, memang iya kadang sekali kutip bisa $3 \mathrm{~kg}$ tapi tentu lama kelamaan makin banyak maka dari itu sampah nya harus dikelola dengan baik agar bermanfaat dan menambah dari pendapatan masyarakat (Responden 1)..."

“...Sebagian sudah ada, kadang sudah dibuang tetap digabungkan lagi untuk dibakar masyarakat walaupun masyarakat sudah diberikan sosialisasi tentang sampah tersebut dari puskesmas antara tahun 2018 atau 2019 (Responden 2)...”

\section{2) Tahap Pengumpulan}

Dimanakah tempat pengumpulan sampah sementara yang dilakukan masyarakat sebelum pengolahan?

“...Kalau untuk sekarang pengumpulan sampah tu dikumpulkan di rumah Pak Sekdes atau Pak Nursalim (KAUR Desa) karena kita sudah sediakan bahan-bahan lainnya untuk diolah sebab dulu sudah pernah ikut pelatihan juga dari tim khusus pertanian (Responden 1)..."

\section{3) Tahap Pengangkutan}

Bagaimana ketersediaan sarana prasarana Desa Parit 1 Api-Api terhadap pengelolaan sampah anorganik? Seperti pengangkutan sampah ke suatu tempat 
“...Kita menggunakan gerobak kan sampah di desa kita ni tergolong kecil (Responden 1)..."

“...Sampah yang dibuang ke tong sampah di pinggir jalan tu diangkut pakai gerobak dibuang juga di sebuah tempat tapi dibakar juga mungkin (Responden 2)...”

\section{4) Tahap Pengolahan}

Bagaiamana bapak/ibu melakukan proses 3R pada sampah anorganik terlebih dahulu ?

“...Cuma kalau untuk sosialisasi nya sudah pernah tapi penerapan ke masyarakatnya sendiri belum ada, artinya kalau barang bekas ini perangkat desa saya sendirilah dalam pembersihan barang bekas tu untuk dijual kembali, ada yang tukang ambil barang bekas nya tapi kalau dari ibu PKK sudah melakukan pengolahan seperti daur ulang menjadi kerajinan seperti tas, dompet juga (Responden 1)..."

Berdasarkan hasil wawancara yang telah peneliti lakukan pada tanggal 1-4 April Tahun 2020 dalam waktu random atau secara acak peneliti mendapatkan beberapa jawaban yang berbeda beberapa juga yang sama, kemudian dibandingkan dengan hasil observasi di Desa Parit 1 Api-Api ini. Dengan beberapa pertanyaan yang peneliti tanyakan kepada aparatur pemerintahan desa mulai dari Kepala Desa, Kepala Dusun, Ketua RT dan Masyarakat, dapat dilihat dari kondisi masyarakat yang hampir secara keseluruhan tidak melakukan pengelolaan sampah anorganik, dan juga sampah yang ada di pasar Desa Parit 1 Api-Api tidak diolah hanya langsung dibakar. Sampah-sampah yang berasal baik dari pemukiman warga dan dari pasar tidak dikelola melainkan langsung dibakar, apabila ada sampah yang masih bisa dijual seperti sampah botol, barulah dilakukan pemilahan, jika tidak ya langusng dibakar saja.

Tidak adanya tempat pembuangan sampah sementara juga menjadi pokok permasalah di desa ini, sarana dan prasarana yang tidak memadai merupakan masalah utama penyebab dari kegiatan pembakaran sampah yang dilakukan masyarakat. Ditambah lagi dengan tidak adanya perhatian pemerintah baik pemerintahan kecamatan maupun pemerintahan desa itu sendiri yang tidak mengalokasikan dananya dalam membantu pengelolaan sampah di Desa Parit 1 Api-APi ini menjadikan masyarakat tetap memilih cara membakar sampah sebagai alternatif pembersihan sampah yang mereka anggap benar. Untuk pengangkutan sampah menuju ke tempat pemrosesan akhir (TPA) tidak ada sama sekali, inilah mengapa masyarakat memilih 
membakar sampah dan tidak melakukan pengelolaan sampah anorganik terlebih dahulu

\section{PEMBAHASAN}

\section{A. SDM (Sumber Daya Manusia)}

Setelah dilakukan wawancara maka didapatlah informasi tang berbeda tentang keterangan mengenai ketersedian tenaga kerja dan Pengelolaan Sampah Anorganik di Desa Parit 1 Api-Api, Kepala Desa mengatakan bahwasannya sudah ada tim khusus dalam penanganan sampah di desa tersebut sementara Kepala Dusun mengatakan bahwasannya hanya ibu PKK yang menjadi pengelolaan sampah anorganik tetapi itu tidak berjalan lagi dan Ketua RT dan Masyarakat mengatakan bahwasannya tidak ada SDM dalam pengelolaan sampah Anorganik di Desa Parit 1 Api-Api. Dari hasil wawancara tersebut dapat diambil kesimpulan bahwasannya saat ini di Desa Parit 1 Api-Api tidak adanya Sumber Daya Manusia dalam melakukan pengelolaan sampah Anorganik tersebut. Tidak adanya kerjasama pemerintah terhadap desa dalam penyedia dana maupun sarana prasarana dalam pengelolaan sampah menyebabkan Sampah yang dihasilkan dari aktivitas masyarakat setiap hari maupun dari aktivitas pasar yang di adakan sekali seminggu tidak dilakukan pengelolaan dan hanya dengan cara dibakar. Hal ini dapat menyebakan timbulnya penyakit dan kerusakan alam jika dilakukan terus menerus tanpa berhenti.

Menurut PP. No 81 Tahun 2012 dalam penyelenggaraan penanganan sampah, pemerintah kabupaten atau kota memungut retribusi kepada setiap orang atau jasa pelayanan yang diberikan. Retribusi sebagaimana dimaksud ditetapkan secara progresif berdasarkan jenis, karakteristik, dan volume sampah.

Tenaga kerja manusia (human labor) adalah salah satu sumber daya terpenting yang dibutuhkan oleh berbagai kegiatan operasi dan produksi. Pada berbagai kegiatan tenaga kerja manusia ini dapat melaksanakan pekerjaan yang dilaksanakan membutuhkan tenaga yang besar, kecepatan dan ketepatan yang tinggi, manusia dibantu oleh mesin dan peralatan. Namun demikian tidak ada pekerjaan yang dapat diselesaikan tanpa keterlibatan tenaga kerja manusia. Manusia melaksanakan kegiatan pengelolaan dimana hal yang mendasari pelaksanaan kegiatan adalah pemenuhan kebutuhan manusia. Pemanfaatan tenaga kerja haruslah didasarkan antara keselarasan pekerjaan tenaga kerja itu ssendiri.

Pemanfaatan tenaga kerja haruslah didasarkan antara keselarasan pekerjaan dan tenaga kerja itu sendiri. Daya hasil seseorang tanpa kerja ditentukan oleh tingkat keselarasan tersebut. Apabila seorang tenaga kerja sudah dipekerjakan, dan apabila ternyata bahwa 
tingkat keselarasan tertinggi antara tenaga kerja itu tidak dapat diwujudkan maka perusahaan harus mengusahakan perubahan pada jenis kegiatan pekerjaan itu sendiri yang berarti menyesuaikan dengan tenaga kerja yang telah dipekerjakan. Penyesuaian itu dapat berbentuk perubahan pada jenis kegiatan, tata cara melaksanakan kegiatan, peralatan yang dibutuhkan dan digunakan, ataupun tempat melaksanakan pekerjaan.

Sama halnya dengan penelitian Sartika (2018) pada Pengelolaan Pasar Kayu Jati bahwa tenaga kerja kebersihan pada pengelolaan sampah pasar sangat berpengaruh, volume sampah pasar yang banyak sementara tenaga kebersihan sedikit mengakibatkan tidak terkelolanya dengan baik sampah pasar tersebut.

Menurut analisa peneliti untuk ketersediaan tenaga kerja dalam melakukan pengolahan sampah khususnya sampah anorganik saat ini sudah tidak tersedia, padahal sebelumnya sudah ada ibu PKK yang melakukan tetapi hanya berjalan 1 tahun pertama di tahun 2016 dan setelah itu tidak berjalan lagi, keterangan tersebut didapat pada wawancara terhadap Kepala Dusun. Maka dari pada itu perlu nya ketegasan dari Pemerintahan Desa untuk mengaktifkan kembali ibu PKK dalam pengelolaan sampah di Desa Parit 1 Api-Api khususnya sampah Anorganik.

\section{B. Anggaran}

Setelah dilakukannya wawancara dengan Kepala Desa, Kepala Dusun, Ketua RT dan Masyarakat Desa Parit 1 Api-Api Kecamatan Bandar Laksamana, peneliti menemukan jawaban yang berbeda, Kepala Desa mengatakan bahwasannya dana/aanggaran dalam melakukan pengelolaan sampah di desa tersebut sudah ada dana tersendiri yang dikeluarkan untuk pengelolaan sampah sementara Kepala Dusun mengatakan hingga saat ini dana tersebut hanya wacana dan tidak ada dilaksanakan juga Ketua RT dan Masyarakat mengatakan tidak adanya iuran kebersihan dalam melakukaan pengelolaan sampah anorganik di Desa Parit 1 Api-Api.

Hal ini peneliti anggap salah satu penyebab tidak dilakukannya pengelolaan sampah dipasar karena upah yang tidak ada bagi para pekerja, sehinggap tidak tercapainya pengelolaan sampah secara maksimal. Maka dari itu diketahuilah bahwa pengelolaan sampah anorganik di Desa Parit 1 Api-Api belum terlaksana dengan benar, pengelolaan sampah anorganik tidak dapat terlaksana secara maksimal karena tidak adanya pengalokasian dana yang jelas untuk memfasilitasi desa dalam melakukan pengelolaan sampah anorganik di Desa Parit 1 Api-Api Kecamatan Bandar Laksamana. Masyarakat di 
Desa Parit 1 Api-Api beranggapan bahwasannya dengan cara membakar sampah merupakan satu-satunya cara ampuh untuk mengatasi permasalahan sampah yang ada di desa ini.

Sesuai dengan Undang-undang Nomor 81 tahun 2012 pengelola kawasan pemukiman, kawasan komersial, kawasan industri, kawasan khusus, fasilitas umum, fasilitas sosial, dan fasilitas lainnya dalam melakukan pengumpulan sampah wajib menyediakan TPS, TPS 3R atau alat pengumpul untuk sampah terpilah. TPS atau TPS 3R sebagaimana yang dimaksud harus memenuhi persyaratan yaitu tersedia sarana untuk mengelompokkan sampah menjadi paling sedikit lima jenis sampah, luas lokasi dan kapasitas sesuai kebutuhan, lokasinya mudah di akses, tidak mencemari lingkungan dan memiliki jadwal pengumpulan dan pengangkutan.

Menurut Sudiro, dkk (2018), sampah yang dibuang dengan cara ditumpuk begitu saja maka akan menimbulkan bau dan gas yang berbahaya bagi kesehatan manusia. Selain itu tradisi membuang sampah disungai atau parit dapat mengakibatkan pendangkalan begitu cepat.

Sama halnya dengan penelitian Sartika (2018) Sampah Pasar Kayujati Tembilahan Kabupaten Indragilir Hilir setiap pelaksanaan suatu program tidak luput dari rencana anggaran biaya. Adapun alokasi biaya pada pengolahan sampah meliputi, Honor petugas, pembeliaan alat-alat, biaya operasional dan pemeliharaan aat-alat, pembelian tanah untuk lokasi kantor, TPS serta TPA, hingga pembiayaan lain-lain seperti listrik, air, telepon, dan lainnya.

Menurut analisa peneliti, dalam anggaran ataupun dana untuk pengelolaan sampah di Desa Parit 1 Api- Api tidak adanya pengalokasian tersebut, sebab itu perlu nya pengalokasikan dana untuk pengelolaan sampah agar sampah di desa dapat terkelola dengan baik.

\section{Sarana dan Prasarana}

Dari hasil wawancara yang dilakukan bahwasannya sarana dan prasarana pembuangan sampah di Desa Parit 1 Api-Api sudah ada yaitu berupa tong sampah yang berada di pinggir jalan tetapi ada juga Masyarakat yang mengatakan bahwasannya saran tersebut tidak sampai ke sekitar lingkungannya. Tetapi walaupun sarana untuk pembuangan sampah tersebut sudah ada nyatanya dilapangan dan hasil wawancara yang dilakukan, masyarakat Desa Parit 1 Api-Api tetap tidak membuang sampah ke tong tersebut akibat sampah yang sudah dibuang masyarakat ke dalam tong tersebut apabila dilihat beberapa hari ke depan akan sama seperti itu juga, maka dari itu masyarakat lebih memilih untuk membakar sampah tersebut, dan peneliti juga menemukan masyarakat yang masih membuang sampah 
sembarangan. Tidak adanya TPS (tempat pembuangan sementara) serta sistem pengelolaan yang disediakan pemerintah daerah dan desa membuat masyarakat mau tidak mau harus memilih membakar sampah yang mereka hasilkan setiap harinya.

Sesuai dengan Undang-undang Nomor 81 tahun 2012 pengelola kawasan pemukiman, kawasan komersial, kawasan industri, kawasan khusus, fasilitas umum, fasilitas sosial, dan fasilitas lainnya dalam melakukan pengumpulan sampah wajib menyediakan TPS, TPS 3R atau alat pengumpul untuk sampah terpilah. TPS atau TPS 3R sebagaimana yang dimaksud harus memenuhi persyaratan yaitu tersedia sarana untuk mengelompokkan sampah menjadi paling sedikit lima jenis sampah, luas lokasi dan kapasitas sesuai kebutuhan, lokasinya mudah di akses, tidak mencemari lingkungan dan memiliki jadwal pengumpulan dan pengangkutan. Pengumpulan sampah merupakan sebuah tanggung jawab dari individu baik rumah tangga atau institusi yang menghasilkan sampah. Karena itu perlunya mengadakan pembangunan tempat khusus untuk mengumpulkan sampah. Kemudian dari masing-masing TPS sampah, dan selanjutnya ke TPA (Taufiqurrahman, 2016).

Bentuk pasrtisipasi masyarakat dalam membuang sampah ditempat yang telah disediakan cenderung rendah. Apalagi jika tidak tersedianya sarana dan prasarana pembuangan sampah. Dari hasil wawancara dengan responden masyarakat Desa Parit 1 ApiApi pengelolaan sampah anorganik Tbanyak nya dari warga itu sendiri melakukan pengelolaan sampah anorganik dengan cara membakar sampah, da nada juga masyarakat yang membuang sampah sembarangan walaupun telah tersedia sarana pembuangan sampah seperti tong sampah, nyatanya masih banyak masyrakat yang tidak membuang sampah ke tong tersebut akibat tidak adanya penanganan lebih lanjut setelah sampah itu dibuang sehingga masyarakat lebih memilih membakar sampah dari pada melakukan pengolahan terlebih dahulu. Sama halnya dengan penelitian Fitra (2017) pada Pengelolaan Sampah Pasar Ujung Batu tidak meratanya ketersediaan sarana dalam bentuk tong sampah mengakibatkan berserakannya sampah di sudut kios pedagang.

Menurut analisa peneliti, sarana dan prasarana telah diberikan oleh pemerintahan desa dalam pengelolaan sampah seperti tong sampah walaupun belum merata, tetapi akibat kurangnya kesadaran beberapa masyrakat mengakibatkan tidak efektifnya sarana dan prasarana tersebut. Karena itu perlunya kesadaran dan pemerataan terhadap sarana dan prasarana yang diberikan oleh pemerintahan desa, untuk masyarakat desa harus diberikan pemahaman untuk buang sampah pada tempatnya dan menghilangkan kebiasaan lama yaitu membakar sampah 


\section{SIMPULAN}

Berdasarkan dari hasil penelitian dan pembahasan tentang Pengelolaan Sampah Anorganik Di Desa Desa Parit 1 Api-Api Kecamatan Bandar Laksamana Tahun 2020 maka dapat di ambil kesimpulan sebagai berikut :tenaga kerja yang tidak tersedia untuk melakukan pengumpulan, pengelolaan sampah anorganik di Desa Desa Parit 1 Api-Api Kecamatan Bandar Laksamana Tahun 2020, tetapi untuk tenaga kerja pengelolaan sampah pasar sudah tersedia. Masyarakat melakukan pengelolaan dengan cara membakar sampah. Dana/anggaran desa khusus untuk pengelolaan sampah anorganik yang tidak tersedia menyebabkan masyarakat masih membakar sampah sebagai solusi utama untuk pemusnahan sampah di Desa Desa Parit 1 Api-Api Kecamatan Bandar Laksamana Tahun 2020. Sarana prasarana yang tersedia tidak merata dan tidak berjalan efektif TPS (tempat pembuangan sementara) yang tidak tersedia, hingga kendaran pengangkut sampah, menyebabkan.

\section{SARAN}

Hampir seluruh masyarakat membakar sampah sebagai pilihan utama, hasil sampah dari masyarakat lalu dikumpul ditempat pembakaran yang ada pada setiap rumah, setelah itu langsung mereka bakar sebagai tahapan pengelolaan sampah anorganik di Desa Desa Parit 1 Api-Api Kecamatan Bandar Laksamana Tahun 2020. Tidak adanya tahapan pemilahan, pengumpulan, pengangkutan dan pengolahan untuk mengelola sampah anorganik, seperti yang telah peneliti dapatkan dalam hasil observasi lapangan dan wawancara mendalam bahwasannya masyarakat melakukan pengolahan sampah dengan cara dibakar, tidak ada ditemukan cara masyarakat melakukan pengelolaan sampah anorganik di Desa Desa Desa Parit 1 Api-Api Kecamatan Bandar Laksamana Tahun 2020 selain di bakar. Pengelolaan sampah anorganik di Desa Parit 1 Api-Api hanya dengan cara membakar sampah, masyarakat belum paham dampak bahaya kesehatan yang dapat di timbulkan dari perilaku membakar sampah di Desa Desa Parit 1 Api-Api Kecamatan Bandar Laksamana Tahun 2020.

\section{UCAPAN TERIMAKASIH}

Ucapan terima kasih ditujukan kepada Desa Parit 1 Api-Api yang telah memberikan izin penelitian. 


\section{DAFTAR PUSTAKA}

Fitra, R (2016). Analisis Sistem Pengelolaan Sampah di Pasar Baru Ujung Batu Kecamatan Ujung Batu Kabupaten Rokan Hulu. Pekanbaru: STIKes Hang Tuah

Kunci, K., Masyarakat, P., \& Sampah, M. P. (2017). Melalui Pengolahan Sampah Organik Dan Non Organik Di. 4, 281-289.

Kusminah, I. L. (2018). Penyuluhan 4r ( Reduce, Reuse, Recycle, Replace ) Dan Kegunaan Bank Sampah Sebagai Langkah Menciptakan Lingkungan Yang Bersih Dan Ekonomis Di Desa Mojowuku Kabupaten Gresik. 03(01), 22-28.

Mahmudah, R. A., \& Herumurti, W. (2016). Analisis Sistem Pengangkutan Sampah Di Wilayah Surabaya Utara. Jurnal Teknik Its, 5(2). Https://Doi.Org/10.12962/J23373539

.$V 5 i 2.17118$

Marleni, Y., Mersyah, R., \& Brata, B. (2018). Strategi Pengelolaan Sampah Rumah Tangga Di Kelurahan Kota Medan Kecamatan Kota Manna Kabupaten Bengkulu Selatan. Naturalis: Jurnal Penelitian Pengelolaan Sumber Daya Alam Dan Lingkungan, 1(1), 35-40. Https://Doi.Org/10.31186/Naturalis.1.1.5915

Marliani, N. (2014). Pemanfaatan Limbah Rumah Tangga ( Sampah Anorganik

) Sebagai Bentuk Implementasi. 4(2), 124-132.

Notoadmojo, S. 2011. Kesehatan Masyarakat IImu Dan Seni. Cetakan 2011. Jakarta. Rineka Cipta

Peraturan Daerah Kabupaten Bengkalis Nomor 02 Tahun 2015 Tentang Pengelolaan Sampah

Sahil, J., Henie, M., Al, I., Rohman, F., \& 2020 Jam 17:05

Syamsuri, I. (2016). Sistem Pengelolaan Dan Upaya Penanggulangan Sampah Di Kelurahan Dufa- Dufa Kota Ternate. Sanitasi Lingkungan, 4(2), 478-487.

Sartika (2018). Analisis Pengelolaan Sampah Pasar Kayujati Tembilahan Kabupaten Indragilir Hilir. Pekanbaru: STIKes Hang Tuah.

Sumantri, A. (2010). Kesehatan Lingkungan. Cetakan 2010 Jakarta. Kencana Prenada Media Group.

Suryati, Teti. (2014). Bebas Sampah Dari Rumah. Cetakan 2014 Jakarta Agromedia Pustaka. Undang-Undang Republik Indonesia Nomor 18 Tahun 2008 Tentang Pengelolaan Sampah. Undang-Undang Republik Indonesia Nomor 81 Tahun 2012 Tentang Pengelolaan Sampah Rumah Tangga Dan Sampah Sejenis Sampah Rumah Tangga. 
Yulianto, B. (2016). Partisipasi Pedagang Dalam

Melakukan Pemilahan

Sampah Di Pasar Baru Kecamatan Tampan Kota Pekanbaru. Jurnal Kesehatan Komunitas, 3(2), 69-72. Https://Doi.Org/10.25311/Jkk.Vol3.I ss2.105

Https://Ekonomi.Bisnis.Com/Read/2019022 1/99/891611/Timbulan-Sampah- NasionalCapai-64-Juta-Ton-Per- Tahun. Diakses 24 Januari 2020 Jam14.15 Https://Radarbali.Jawapos.Com/Read/2019/0 6/26/143132/Mesin-Pengolah- Sampah-DlhBuleleng-Sanggup- Ubah-Sampah-Jadi-Bbm. Diakses 27 Januari 